\title{
DIGITAL SOCIETY AS “A SNEER OF HISTORY”
}

\section{Abstract}

The article examines digital society from a historiosophical point of view using such Hegel's category as universal world irony. It is stated that the implementation of the Modern project based on the principles of rationalism and anthropocentrism has led to the threat of dehumanization of society and desocialization of a human. The digital society is interpreted as the result of a specific social practice with relevant actors and goals. The origins of the technocratic development of society are found in the sphere of politics and the constructive-projective attitude towards society and a human, characteristic of the Enlightenment ideology. The example of the education sector illustrates that criticism and denial of traditional institutions and forms of social communication are explained by the impossibility of subjecting them to complete digitalization and, accordingly, to the process of political and bureaucratic control. Hegel's "irony of history" manifested itself in the fact that science, emancipated from religion and philosophy, within the framework of modern digital reality, obediently turns into "a maidservant" of technology and technocrats.

Key words: digital society, historiosophy, irony of history, modern project, politics, technocrats, education.

DOI: 10.51180/RPS.2020.15.2.007.

\section{Author}

\section{Nasyrov Rafail Valeizyanovich,}

Associate Professor of the Department of Theory and History of Altai State University, $\mathrm{PhD}$ of Legal Sciences

(Barnaul, Russia)

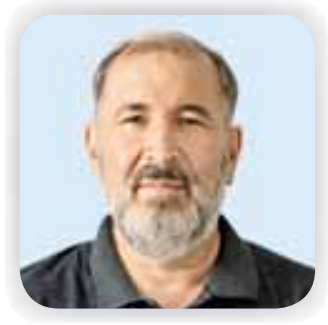

\section{Introduction}

ᄂ he title of this article reflects the goal of considering the modern stage of civilization development from a historiosophical point of view, which presupposes not only a broad chronological framework for studying the origins of this or that phenomenon, but, above all, consideration of the problem in the context of questions about the purpose and meaning of human existence and the history of humankind in general. But the description and evaluation of modern society as a digital (postindustrial, information) one is based on the idea (more precisely, prejudice) of technological determinism, which, by the "irony of history", acquires a special kind of fatalism and even hidden quasi- religious eschatologism. It can be argued that this fatalism, clothed in scientific and technical terminology, is a simulacrum and a rudiment of previous historiosophical ideas about the providence of God, the end of the world, etc. An "iron" consistent pattern appears - if a person does not believe in something sublimely transcendent, absolute, then a person starts to worship the idols of science and technology of our time. Amazing digital technologies fascinate and entice in the traditional meaning of these words. The term "digital madness" has appeared in the speech of intellectuals, along with the already popular phrases such as "obsession with gadgets", "digital addiction", "digital dementia", etc. [12]. 


\section{Modern technocratic era in the light of philosophy}

It is appropriate to recall Hegel, his concept of universal world irony, which "admits the truth of what is immediately taken to be true, but only in order to reveal that inner destruction that is contained in these same assumptions" [6. - P. 45]. In recent times much has been said about the Socratic irony which, like all dialectic, gives force to what is - taken immediately, but only in order to allow the dissolution inherent in it to come to pass; and we may call this the universal irony of the world. The modern era should be viewed in the context of a general background - the "sarcastic grin" of history over the anthropocentric and self-confident rationalism of the Enlightenment. Descartes's quote "I think, therefore, I am" already contained in itself the danger, not envisioned by Cartesius himself, of reducing human consciousness only to intellect, the owner of which, as it turned out, could be not only a human, but also a machine. F. Bacon's optimistic thesis "Knowledge is power" means knowledge that a person discovers and uses. But in modern conditions, when artificial intelligence (Al) will be the bearer and producer of this knowledge, this thesis acquires a completely different, rather sinister character - scientific knowledge has become a powerful force, but out of human control.

Modern scholars have been actively involved in the process of constructing various scenarios of the "end of the world" - nuclear war, environmental disaster, biotechnology which has come out of control, etc.; the question of how to preserve the accumulated knowledge for future civilizations after the death of modern humanity is being discussed [8]. The "quiet" version of the end of the world is contained in the descriptions of the state of society, human and nature (more precisely, "post-society", "post-human", "post-nature") after the onset of the socalled "point of technological singularity". History is exactly "grinning" at secularized humanism, the proclamation of a human as the highest value, since in the near future Al will significantly surpass a human one, technology will begin to reproduce and improve itself, and the only way for a person to preserve himself or herself in this new technological reality is to stop being a human. The era of "post-human" is coming: "Post-human is a person modified with the help of the latest and future technologies to such an extent that from the modern conventional point of view, it is no longer a human ... Post-humans may be completely artificial creatures (based on artificial intelligence) or the outcome of a large number of changes and improvements in human or transhuman biology. Some post-humans may even find it useful to give up their own body and live as information structures in giant super-fast computer networks." [11].

It is more tactful to talk about a simplified, pragmatic-handicraft perception of the ideas of the Enlightenment thinkers, whose worldview was more complex and multidimensional in comparison with the flat consciousness of modern scientists and technocrats. It turned out that the "energetic" source of the Enlightenment humanistic ideology was the former religious worldview, the grounds and horizon of which did not disappear immediately. Voltaire could still claim that he meets with God, nods his head to him, but does not talk to him. In the 19 th century, when the religious source of the worldview began to dry out and acquired only a formal character, F. Nietzsche diagnosed "God is dead". This means that Hegel's prediction concerning the end of world history with the establishment of the dominance of Reason was not justified; in his philosophical system, it was not supposed to abolish religion, but its unity with art in the bosom of the Absolute Idea [5. - P. 393].

In recent decades, in Russia as a country of incomplete modernization (an archemodern society as A. Dugin describes), one could personally observe the completion of this process of "dying of God", that is, "soul deprivation" and 
"despiritualization" the very fabric of social life. The idea of science as a temple of knowledge and a place of selfless service to the Truth has disappeared, and education has ceased to be perceived as a sphere where "rational, good, and eternal are being sown." B.V. Markov writes: "Comparing modern pedagogical practices with the ancient forms of mentoring and teaching, one cannot but note the loss of the complex technique of transferring traditions and life experience, as well as the awakening and intensification of higher spiritual states and insights." [10. - P. 19-20]. On the whole, it became obvious that the Modern project, having been implemented in the last three centuries, turned out to have not just other, but in many respects opposite results. Representatives of this trend of philosophical and socio-political thought would not see in modern society the embodiment of their ideas about humanism (human-centrism) and rational social organization. A typical representative of postmodern society, who enthusiastically plunges into the world of digital services and goods, is rather a parody of the ideal of a comprehensively and harmoniously developed person.

The digital society did not arise in the process of the objective and inevitable development of science and technology, but has become the result of a certain practice with corresponding subjects and goals. P. Bourdieu, a French sociologist noted: "We are facing the politics of globalization. (I am talking particularly about the "politics of globalization", and not just about "globalization", as if it were a natural process)" [4]. It is also legitimate to say that there is no digital reality, but there is politics of digitalization. The technocratic origins of the societal development are to be sought in political practice, which is authentic to the spirit of the Modern project, its methodology. It turned out that neither a human nor freedom lie at the basis of this project, but "the will to power", a constructive and projective attitude towards society and a human. The most crucial factor of modern social existence and technology of power has become the deliberate immersion of people in a state of feverish consumption of innovative achievements so that a person has lost the very ability to pose and seek answers to fundamental (historiosophical, metaphysical) questions of existence. Therefore, giving a diagnosis to modern society, J. Baudrillard attaches particular importance to such a mass phenomenon as "fascination"; this word takes on not only its direct meaning, but also others, namely hypnosis, blinding and even zombie [2. - C. 11-12, 274]. The philosopher writes: "Consumerist man regards enjoyment as an obligation; he sees himself as an enjoyment and satisfaction business. He sees it as his duty to be happy, loving, adulating/adulated, charming/charmed, participative, euphoric and dynamic" [1. - P. 110].

Even such a respectable representative of the American establishment as A. Gore admits: "We seem to increasingly strive to dissolve in an abundance of forms of culture, society, technology, media, as well as modes of production and consumption, but we pay for all this with the loss of our spiritual life" [7. - P. 243]. The former vice president of the United States offers an eerie but permissible comparison of modern Western society to a collective drug addict who continues to obey his passion, even after his body has already begun to deteriorate. If "natural organs" such as traditional values, institutions, forms of communication are being destroyed, then it is proposed to replace them with artificial (digitized) surrogates.

In order to avoid the accusation of "thickening the colors", we will cite as an example excerpts from the report "The Future of Education: Global Agenda", which claims to be scientific. In this text, the immanent human need for selfdevelopment is imperatively associated with the transformation of the body into an "interface for interacting with the 
digital environment." The formation of the so-called "hybrid personality, combining artificial and natural components within the nervous system with artificial components, including cloud ones," is being predicted. The authors of the report confidently state: "It is obvious that for such hybrid individuals the very idea of learning is fundamentally changing - for example, it is possible to quickly load a skill or knowledge into the "artificial" part, and they will immediately be available to the "natural" part (...) With the advent of direct loading of experience into the nervous system of "hybrid personalities", "forests of consciousness" and other phenomena, it becomes meaningless to talk about pedagogy in its current meaning. Therefore, we consider the "cognitive revolution" and its culmination - the neuronet (the next generation Internet based on neurointerfaces) as technologies that "close" the development of the current cycle of high-tech pedagogy" [3].

This kind of predictions of the pedagogy "progress" is based on sophistry, a rough substitution of concepts - the formation of a personality and the pedagogical process are identified with the technical process of downloading information files, which is comprehensible for programmers. A personality is always the result of self-understanding, self-assimilation of information about the world around us, which for all people (including scientists and IT programmers) is equally endless, unpredictable, mysterious and, finally, dangerous. In social communication, including pedagogical one, there is an interaction of different by the level of development and awareness yet autonomous consciousnesses and corresponding worldviews. Ideally, a teacher should not place a student's consciousness inside his or her worldview, but is called upon to help a student form his or her own one. Interaction, combination, collision of individual worldviews take place in various forms of social communication. Even such phenomena as "suggestion", "suppression of the will", "manipulation of consciousness", "group consciousness", "mass psychology of the masses", etc. are to be considered as characteristics of the interaction process of individual consciousnesses.

No matter how hierarchically society is organized, the very fact of the presence of autonomous consciousnesses and the ability of a person to form his or her own worldview contains the prerequisite for independent thinking. But isn't it possible to develop a scientistic-technocratic utopia and bring it to life when these axioms of social existence and the laws of the individual functioning and social consciousness are being neutralized, in particular, this right and the ability of the individual to form his or her own worldview in consciousness are disappearing? It turns out that amazing and constantly evolving information technology can be used to achieve this goal. The word "worldview" implicitly contains the idea that there is a common world for everyone, including a scientist and a layperson, a programmer and a consumer of digital services, within which they аге equally exist. From the point of view of epistemology, this means that no one has the right to metanarrative in relation to the world as a whole, to its complete comprehension and description. But in the XVII-XVIII centuries natural and technical sciences arose, which not only made amazing discoveries and started forming a rational scientific worldview, but also influenced all spheres of social life. M. Heidegger proves that the worldview that emerged in the Age of Enlightenment has a metaphysical (or antimetaphysical, nihilistic, but still associated with metaphysics) basis. "Machine technology is itself an autonomous transformation of praxis, a type of transformation wherein praxis first demands the employment of mathematical physical science. Machine technology remains up to now the most visible outgrowth of the essence of modern technology, which is identical with 
the essence of modern metaphysics" [13. - P. 41].

Within a special scientific discourse, a corporate metanarrative is needed, i.e. a general and unified system of signs, symbols, categories, axioms. During the last three centuries, the "scientistic temptation" has been embodied in life aiming at a universal character to a specific type of scientific knowledge and replacing all other types. Replacing God, Artificial Super Intelligence (ASI) is granting a human being a new world of previously unseen opportunities; "art projects" instead of works of art as the products of artists' creative inspiration; a "smart machine for housing " instead of a home as a microverse being built by the person himself or herself and so on. However, the "specifics" of this utopia is that scientists put themselves in the position of metanarrative bearers and place society and a human inside their worldview, i.e. the worldview created by them. They suggest everyone else not their own "worldview" (such an honest statement of the question presupposes the recognition of its inevitable limitation, "partialness"), but "the world as a view." M. Heidegger writes about this: "Where the world becomes picture, what is, in entirety, is juxtaposed as that for which man is prepared and which, correspondingly, he therefore intends to bring before himself and have before himself, and consequently intends in a decisive sense to set in place before himself. Hense world picture, when understood essentially, does not mean a picture of the world but the world conceived and grasped as picture" [13. - P. 49]. It becomes clear that soon full immersion of a person in the virtual world is the logical completion of this world projection as a view. But from a political point of view, it is important that those who will create conditions for the functioning of this virtual world will not be fully immersed into it themselves.

The above judgments of $M$. Heidegger were expressed about eighty years ago, but they sound even more relevant today.
The dynamics and forms of imperative and authoritarian implementation of technotronic innovations look absurd: everlasting problems, for example, in the spheres of social communication or education, are not solved with the help of new technical means, but these problems are transformed (as a rule, in the direction of their simplification) in such a way that they can be solved by technical means. At the beginning a computer had appeared, and only after that programmed training was invented, in which a text had become not only a means of preliminary (primary) control of knowledge, but a form of assimilation of educational material, which was to be transformed for this form of control and knowledge assimilation. Therefore, the deconstruction of the traditional education system criticism makes it possible to understand that this system for the "progressives" is not outdated, but too complicated, and not amenable to programming and "digitization".

\section{Pedagogy and education in the modern technocratic era}

In pedagogy, the problem has always been posed: "How to teach to analyze and assimilate information independently by yourself?"; the achievement of this goal, of course, also presupposed the acquisition of essentially technical skills in finding the necessary information (source studies, bibliography, etc.) by the student. But progress in modern education is associated primarily with the development of this (necessary, but not the main) aspect of educational and research activities. Therefore, the above mentioned forecast about the emergence of a new pedagogy arises, in which the teacher will simply "load" the content of the subjects into the student's consciousness. The alarming and obvious findings that the modern student loses the ability to recall information from memory that he has become familiar with in the past are confronted with the 
following objection: this is not necessary, it is important that the learner knows the source of this information. The pretext of the increased amount of information is sly, because the problem has arisen that information ceases to be perceived, but it is only "loading" mechanically into memory and also removing from it easily in the same way. Therefore, $\mathrm{K}$. Lorenz successfully joked: "An expert is one who knows more and more about less and less until he knows absolutely everything about nothing". At the end of this aphorism, the founder of ethology, as it were, foresaw the emergence of the "post-human" ("hybrid personality") project, into the artificial components of which it would be possible to load the contents of all large libraries; then this "something" will "know everything about nothing."

The right of a person to form his or her own worldview is at the same time a burden, since it implies not only an awareness of the orderliness and laws of this world, but also a courageous recognition of its tragedy and danger. What kind of danger are we talking about? At the very least, there must be dualism in thinking. On the one hand, the ability to take into account the innovations arising in society, to take part in their development and positive use. But, on the other hand, the biblical "There is nothing new under the sun!" is always relevant; the deep meaning of these words is a warning against complete immersion in the hustle and bustle of everyday life. The problems of human existence, including those related to the relationship between good and evil, freedom and responsibility, etc. remain essentially unchanged. The development of civilization leads to the fact that the new external conditions of human existence do not allow completely repeating the forms and methods of solving these problems of our ancestors, but the scale for evaluating human life remains unchanged. An educated person does not allow himself or herself to fall into the "prejudice of progress," based on the conviction that the emergence of new conditions and means of social existence, allegedly, predetermines the emergence of a fundamentally new type of person and society. The forms and directions of the modern education "development" serve as an example of how the introduction of innovative technologies emasculates and displaces culture. For millennia, a lively dialogue between a teacher and a learner, the events of their interaction and communication have been the constant and the core of upbringing and education. Entering a school presupposed a conversation between a teacher and an applicant in order to find out his or her ability to become a participant in a special dialogue in the future, the content and forms of which are predetermined by the specialization of a school. The essence of the final examinations was not just about identifying knowledge, but finding out - "Has this graduate become a competent participant in a special corporate dialogue - physicists, chemists, historians, philologists, lawyers, etc." The emergence of such a science as pedagogy made it possible to detail various aspects of education as a special discourse of a teacher and a student, i.e. content, forms and methods. School facilities, such as buildings, furniture, equipment, material carriers of information, etc. were also singled out as an additional element of the educational process, ensuring its external conditions It would have been absurd to put in the first place the means of teaching in this list of elements of the educational process, under which not only the forms and methods of education, but even the content of disciplines should have been transformed. But exactly this absurd scenario of "progress" is being realized at present. Back in 1979 J.F. Lyotard wrote: "The nature of knowledge cannot survive unchanged within this context of general transformation. It can fit into the new channels, and become operational, only if learning is translated 
into quantities of information. We can predict that anything in the constituted body of knowledge that is not translatable in this way will be abandoned and that the direction of new research will be dictated by the possibility of its eventual results being translatable into computer language". [9. - P. 16]. The "implementers" of innovative technologies themselves are like "appendages" of machines, inexorably demanding from teachers and instructors to provide only the functionality and operation of the educational process. A French philosopher drew attention to this totalitarian style of introducing innovations in a postmodern society forty years ago: "In matters of social justice and of scientific truth alike, the legitimation of that power is based on its optimizing the system's performance efficiency. The application of this criterion to all of our games necessarily entails a certain level of terror, whether soft or hard: be operational (that is, commensurable) or disappear" [9. - P. 11].

\section{Conclusion}

In conclusion, we point out that a consistent pattern appeared in the evolution of the new European logos, which resulted in a modern technotronic (digital) society. This pattern is expressed in Schiller's play "The Fiesco Conspiracy in Genoa" - "The Moor has done his work-the Moor can go". At the beginning, philosophy abandoned the status of "the maidservant of theology", then, science that emerged from philosophy declared that it did not need philosophy, and now science, emancipated from theology and philosophy, is meekly becoming "the maidservant of technology." This whole process was originally based on the sublime principle of humanism and the cult of the human mind. But in the near future, reaching "the point of technological singularity" will raise the question of whether a human himself is needed in this new technotronic reality or not. We admit that this is no longer the Hegelian "irony of history", but its evil and malicious "sneer".

\section{References}

1. Бодрийяр Ж. Общество потребления. Его мифы и структура. М.: Республика, 2006. [Baudrillard J. Consumer Society. Its myths and structure. - Moscow: Republic, 2006.]

2. Бодрийяр Ж. Фатальные стратегии. (Пер. с Фр. А. Качалова). - М.: РИПЛ классик, 2017. [Baudrillard J. Fatal strategies. Moscow: RIPL classic, 2017.]

3. Будущее образования: глобальная повестка. — URL: https:// rusinfoguard.ru>wp-content/ uploads/2016/12/GEF (дата обращения: 20.11.2019) [The future of education: a global agenda. - URL: https://rusinfoguard.ruswp-content/uploads/2016/12/GEF (date of reference 20.11.2019)].

4. Бурдье П. За ангажированное знание. - URL: http://magazines.russ.ru/nz/2002/5/burd. (дата обращения 19.08.2020). [Bourdieu P. For engaged knowledge. — URL: http://magazines.russ.ru/nz/2002/5/burd. (date of reference 19.08.2020)].

5. Гегель Г.В.Ф.Энциклопедия философских наук. -Т. 3. - Философия духа. - М.: Мысль, 1977. [Hegel G.V. F. Encyclopedia of Philosophical Sciences. - T. 3. - Philosophy of the spirit. Moscow: Thought, 1977.]

6. Гегель Г.В.Ф. Лекции по философии истории. - Кн. 2. - СПб.: Наука, 2001. [Hegel G.V. F. Lectures on the philosophy of history. Book two. - St. Petersburg: Science, 2001].

7. Гор А. Земля на чаше весов. - М.: ППП, 1993. [Horus A. Earth on the scales. Moscow: PPP, 1993.]

8. Конец света глазами ученых. — URL: https://lotsia.com.ua/article/konec-sveta-glazamiuchenyh: (дата обращения 01.09.19). [End of the world through the eyes of scientists URL:// https://lotsia.com.ua/article/konec-sveta-glazami-uchenyh: (date of reference 01.09.19).]

9. Лиотар Ж-Ф. Состояние постмодерна. - М.: Алетейя, 1998. [Lyotard J.F. The state of the postmodern. Moscow: Aletheia, 1998]

10. Марков Б. Храм и рынок. Человек в пространстве культуры. - Спб.: Алетейя, 1999. [Markov B. Temple and Market. Man in the space of culture. — St. Petersburg: Aleteya, 1999]. 
11. Постчеловечество. — URL: https://transhumanism-russia.гu (дата обращения 12.06.2019) [Posthumanity. - URL: https://transhumanism-russia.ru (date of reference 12.06.2019).]

12. Программа «Тем временем. Смыслы» от 03.09.2019//Телевизионный канал «Культура». [The program "Meanwhile. Meanings", 03.09.2019 / TV channel "Culture".]

13. Хайдеггер М. Время картины мира // Хайдеггер М. Время и бытие: Статьи и выступления. М.: Республика, 1993. [Heidegger M. Time of the picture of the world // Heidegger M. Time and being: Articles and speeches. Moscow: Republic, 1993] 